\title{
Heavy Metal Uptake by Balloon Flower Together with Investigating Soil Properties and Heavy Metal Concentrations in the Cultivated Soils
}

\author{
Jun-Sik Bae ${ }^{\dagger}$, Byoung-Hwan Seo ${ }^{\dagger}$, Sin-Woo Lee, Won-Il Kim, and Kwon-Rae Kim* \\ Department of Agronomy and Medicinal Plant Resources, Gyeongnam National University \\ of Science and Technology, Korea \\ ${ }^{1}$ Chemical Safety Division, National Academy of Agricultural Science, Suwon 441-707
}

(Received: March 24 2014, Accepted: May 26 2014)

Soil properties and heavy metal (HM) concentrations in the field soils where balloon flowers (Platycodon grandiflorum, BF) were cultivated, were investigated together with $\mathrm{HM}(\mathrm{Cd}, \mathrm{Cu}, \mathrm{Pb}$, and $\mathrm{Zn})$ accumulation by the BF roots. Basically, in most soils examined (51-97\% among 65 samples), the chemical properties including soil $\mathbf{~ p H}$, organic matter, available-P, and exchangeable cation contents appeared to be lower than the optimal ranges for balloon flower cultivation. There were no samples exceeding the standard limits for HM in soils. Instead, the total HM concentration levels in soils appeared to be maintained at around background levels for general soil in Korea. This implied that elevated HM accumulation in the soils caused by any possible input sources was unlikely. Even though the BF cultivated soils were not contaminated by HM, it was appeared that substantial amount of $\mathrm{Cd}$ was accumulated in $\mathrm{BF}$ roots with $1.5 \%$ and $35 \%$ roots samples exceeding the standard limits legislated for BF $\operatorname{rot}\left(0.81 \mathrm{mg} \mathrm{kg}^{-1} \mathrm{DW}\right)$ and herbal plants $\left(0.3 \mathrm{mg} \mathrm{kg}^{-1} \mathrm{DW}\right)$, respectively. This implied that the soil HM standard limits based on the total concentration does not reflect well the metal accumulation by plants and also it is likely that the $\mathrm{Cd}$ standard limits for BF and herbal plants is too restrict.

Key words: Contamination, Food safety, Herbal plant, Medicinal plant, Soil

Heavy metal (HM) concentrations in soils and cultivated balloon flower roots and comparison with backgnound value and guideline values for HM in balloon flowers, respectively.

\begin{tabular}{cccccc}
\hline \hline & Cd in soil & $\begin{array}{c}\text { Background } \\
\text { value in soil }\end{array}$ & Cd in root & $\begin{array}{c}\text { Guideline for } \\
\text { medicinal plant }\end{array}$ & $\begin{array}{c}\text { Guideline for balloon flower } \\
\text { as vegetable }\end{array}$ \\
\hline Min & 0.01 & - & 0.20 & - & - \\
Max & 0.36 & - & 0.88 & 0.30 & - \\
Ave & 0.12 & 0.19 & 0.36 & $\left.\mathrm{mg} \mathrm{kg}^{-1} \mathrm{DW}\right)$ - & 0.81 \\
\hline
\end{tabular}

\footnotetext{
$\dagger$ Both authors were equally contributed on this article.

*Corresponding author : Phone: +82557513223, Fax: +82557513229, E-mail: kimkr419@gntech.ac.kr

${ }^{\S}$ Acknowledgement: This study was carried out with the support of "Research Program for Agricultural Science \& Technology Development (Project No. PJ009828012013)”, National Academy of Agricultural Science, Rural Development Administration, Republic of Korea and this work was also supported by Gyeongnam National University of Science and Technology Grant in 2013.
} 


\section{Introduction}

약용작물은 부가가치가 높은 작물로써 농가의 소득증대 를 목적으로 재배가 확산되고 있으며 최근에는 생약의 원료 뿐만 아니라 나물용 채소로도 이용 되고 있다. 소득증대를 위해서는 생산량의 증대와 더불어 생산된 약용작물의 효능 및 안전성이 확보되어야 한다. 생산단계에서 단위면적당 안 정적인 생산량 증대를 위해서는 각 약용작물에 대한 영농기 술 개발과 보급이 필요하며, 이는 각 약용작물 재배지에 대 한 토양정보를 바탕으로 체계적으로 이루어져야 할 필요가 있다. 그러나 지금까지 약용작물 재배지에 대한 토양조사는 매우 미흡한 실정이다.

약용작물 안전성과 관련해서는 최근에 유통되고 있는 한 약재에서 기준치 이상의 중금속 검출 등이 사회적 문제로 대두되어 약용작물에 대한 신뢰성 하락과 이로 인한 소비위 축으로 이어지는 문제가 발생하고 있다. 많은 경우 중금속 검출과 관련해서 중국산 한약재가 문제가 되고 있지만 (Lee et al., 2003; Lee et al., 2010), 최근 경상북도 영천에서 구 입한 한약재에서 납 농도가 $3000 \mathrm{mg} \mathrm{kg}$ 인 한약재를 사용 한 피해사례가 언론에 보도되는 등 (2013.4.16 부산일보) 국 내산 약용작물의 중금속 기준초과 문제도 배제 할 수 없다. 현재 우리나라에서는 약용작물에 대한 중금속 기준을 약사 법의 '생약 등의 잔류·오염물질 기준 및 시험방법'에 고시하 고 있는데, 식물성 생약에 대해 납은 건물중 기준 $5 \mathrm{mg} \mathrm{kg}^{-1}$ 이하, 비소는 $3 \mathrm{mg} \mathrm{kg}^{-1}$ 이하, 수은은 $0.2 \mathrm{mg} \mathrm{kg}^{-1}$ 이하, 카 드뮴은 $0.3 \mathrm{mg} \mathrm{kg}^{-1}$ 이하로 하고 있다 (KFDA, 2010). 최근 에는 여러 약용작물을 채소류로 이용하게 되면서 식품위생 법의 '식품의 기준 및 규격'에 농산물 중금속 기준으로써 더 덕, 도라지, 인삼에 대해서 생중량 기준으로 납은 $2.0 \mathrm{mg} \mathrm{kg}^{-1}$, 카드뮴은 $0.2 \mathrm{mg} \mathrm{kg}^{-1}$ 으로 적용 기준을 고시하고 있다 (MAFRA, 2011).

생산단계에서 약용작물에 노출되는 중금속 오염원은 크 게 두 가지로 나누어 생각할 수 있다. 첫째는 폐금속광산의 영향을 받아 중금속 농도가 높은 농경지에서 약용작물을 재 배하는 경우로 한국광해관리공단은 우리나라에 현재까지 2166 개의 폐금속 광산이 전국에 산재해 있다고 보고하고 있 다 (MIRECO, 2012). 또한, 광산 인근 농경지가 중금속에 오 염되었다는 많은 연구 결과가 발표되어 왔다 (Hwang et al., 2000; MoE, 2012). 두 번째는 가축분뇨를 원료로 만든 퇴비 내 잔류하고 있는 중금속을 들 수 있다. 가축분뇨에는 사료 첨가제로 사용되는 구리와 아연과 같은 중금속이 잔류하고 이를 원료로 제조한 퇴비에도 중금속이 존재하게 된다 (Franco et al., 2006; Rio et al., 2011). 최근 정부 정책에 따라 가축분 퇴비 사용량이 꾸준히 증가하고 있어 농경지에 중금속이 축적될 개연성이 높으며, 결과적으로 농경지에서 재배되고 있는 작물에 중금속 축적 농도가 높아질 가능성이
있다고 할 수 있다. 따라서, 현재 약용작물을 재배하고 있는 농경지에 대한 중금속 농도 분포 조사 및 재배되고 있는 약 용작물의 중금속에 대한 흡수 특성 조사는 추후 약용작물의 중금속 흡수 저감 기술 개발과 같은 연구와 연계하여 매우 중요한 자료로 활용 될 수 있다.

도라지는 경남 지방에서 재배되고 있는 주요약용작물 중 의 하나로써 2009년부터 재배 농가 수 및 소득이 급격히 증 가하고 있다. 2010 년 통계에 의하면 전국적으로 도라지 재 배농가 호수는 경남이 가장 많으며, 생산량은 강원도에 이 어서 2 위를 차지하고 있다. 도라지 1 년근과 2 년근은 주로 채소류로 유통이 되고 있으며 3년근 이상은 약용으로 유통 이 되고 있어 약사법과 식품위생법상의 두 기준이 목적에 따라 적용되게 된다.

본 연구는 주요 약용작물 중의 하나이며 채소로도 이용 되고 있는 도라지를 대상으로 주요재배지인 경남과 강원도 의 재배지 토양특성과 함께 중금속 노출 정도 및 흡수 특성 을 조사하기 위하여 실시하였다. 또한 본 연구는 연구결과 를 생산단계에서 양분관리를 위한 기초자료와 중금속으로 부터 안전한 약용작물 생산을 위한 기술 및 정책 개발의 기 초자료로 활용하는데 목적을 두고 있다.

\section{Materials and Methods}

조사대상지역 및 시료 채취·조제 주 조사 대상지는 경상남도 지역으로 사천시와 함안군을 포함해 7 개 시·군 지 역에서 도라지를 재배하고 있는 21 개 농가를 대상으로 서로 다른 필지에서 토양시료와 도라지 시료를 각각 47개씩 채취 하여 조사하였다. 또한 지역간 비교를 위해서 강원도 3 개 시·군에서 8개 농가를 대상으로 토양과 도라지 시료를 각각 18 개를 채취하여 조사하였다. 시료채취는 2013년 7월과 10 월 사이에 실시하였다. 동일한 필지에서 $3 \mathrm{~m}$ 이상의 이격 거리를 두고 3 개의 토양시료를 $20 \mathrm{~cm}$ 깊이 이내에서 채취 하여 하나의 시료로 조제하였으며, 각 토양을 채취한 자리 에서 자라고 있는 도라지 뿌리를 2-3개씩 확보하여 총 6-9 개의 도라지 뿌리를 하나의 식물시료로 조제하였다. 채취한 도라지의 재배 연수는 각 농가에 설문형식으로 조사하였으 며, 1 년생부터 10 년생까지 분포하는 것으로 조사되었다.

각 토양시료는 풍건하여 $2 \mathrm{~mm}$ 채로 쳐서 분석에 이용하 였다. 도라지 시료는 뿌리를 이용하는 약용작물의 세척 과 정을 모사하기 위해서 껍질을 벗기지 않고 흐르는 수돗물에 서 가정용 세척솔을 이용하여 세척한 후 건조기 $\left(65^{\circ} \mathrm{C}\right)$ 에서 72 시간 건조하였다. 건조한 도라지 뿌리는 분쇄기를 이용하 여 가루로 만들어서 분석에 이용하였다.

분석 항목 및 분석방법 도라지 재배 토양의 영양진 단을 위해서 토양 $\mathrm{pH}$, 전기전도도, 총질소, 유기물, 유효인 
산, 치환성 양이온 함량 및 토성 분석을 실시하였다. 재배 토양의 중금속 노출 정도 및 도라지의 중금속 흡수 특성을 알아보기 위해서 토양 중 중금속 함량을 총함량과 식물유효 태 함량으로 구분하여 분석하였으며, 도라지 뿌리 내 중금 속 함량을 건물중 기준으로 분석하여 비교 평가하였다. 도 라지 건물중 기준의 분석 수치를 생체중 기준으로 전환하기 위해서 각 도라지 시료의 건조 전후 중량을 측정하여 수분 함량을 계산하였다.

토양의 $\mathrm{pH}$ 와 $\mathrm{EC}$ 는 토양과 증류수를 1:5의 비율로 한 시 간 교반 후 $\mathrm{pH}$ (MP220, Mettler Toledo, Switzerland) 및 EC 측정기 (MC226, Mettler Toledo, Switzerland)로 측정하였 다. 토양 유기물과 총질소 함량은 $\mathrm{C} / \mathrm{N}$ 자동원소분석기 (Trumac series. Leco. USA)를 이용하여 분석하였고, 유효인산은 Bray No1 방법으로 정량하였다 (Bray and Kurtz 1945). 점토 함 량은 마이크로피펫법 (Miller and Miller, 1987)으로 분석하 였다. 치환성 양이온 $(\mathrm{Ca}, \mathrm{Mg}, \mathrm{K}, \mathrm{Na})$ 은 $1 \mathrm{~N}$ 초산 암모니아 법 (Sumner and Miller, 1996)에 따라 추출하여 Whatman No. 42 (pore size $2.5 \mathrm{~cm}$ ) 여과지로 여과한 후 ICP-OES (8300DV, Perkin Elmer, USA)로 정량하였다. 토양 중 중금속의 총함 량 측정을 위해서 각 토양 시료 $1 \mathrm{~g}$ 에 $9 \mathrm{~mL}$ 의 왕수를 넣고 흑연블럭분해기 (OD-98-001, ODLAB, Korea)로 분해하고 (NAAS, 2010) 분해 용액을 Whatman No. 42 (pore size 2.5 um) 여과지로 거른 후 용액 중 중금속의 함량을 ICP-OES (8300DV, Perkin Elmer, USA)로 측정하였다. 토양 분해를 위한 각각의 분해 세트에는 표준시료 (Montana Soil SRM 2711, National Institute of Standards \& Technology)와 공 시료를 포함시켜 분해가 적절히 완료되었는지를 점검하였 다. 토양 중 중금속의 식물유효태 농도는 $1 \mathrm{M} \mathrm{NH}_{4} \mathrm{NO}_{3}$ 추출 법으로 다음과 같이 정량하였다 (DIN, 1995). 토양 $10 \mathrm{~g}$ 을 $20 \mathrm{~mL}$ 의 $1 \mathrm{M} \mathrm{NH}_{4} \mathrm{NO}_{3}$ 로 추출하여 여과한 후 침출액 속의 중금속 함량을 ICP-OES로 측정하였다. 도라지 뿌리의 중
금속 농도를 측정하기 위해서 $0.5 \mathrm{~g}$ 의 시료와 진한 질산을 분해관에 넣고 흑연블럭분해기 (OD-98-001, ODLAB, Korea) 로 완전 분해하여 Whatman No. 42 (pore size $2.5 \mathrm{~cm}$ ) 여과 지로 여과한 후 용액 중 중금속의 함량을 ICP-OES (8300DV, Perkin Elmer, USA)로 측정하였다. 식물 시료 분해도 토양시 료와 마찬가지고 표준시료 (1570a trace elements in Spinach, National Institute of Standards \& Technology)와 공시료 를 동시에 분해하여 분해과정을 검정하였다.

데이터 분석 도라지 재배 농경지 토양의 화학적 특성 분석 결과는 양분관리를 위한 자료 제공을 위해서 국립농업 과학원이 휽토람 (http://soil.rda.go.kr/soil/index.jsp)을 통 해서 제공하는 도라지 재배 토양의 화학적 성분 적정 범위 와 비교 평가하였다. 도라지의 중금속 노출 정도는 약사법 과 식품위생법에 고시되어 있는 두 가지 기준 수치와 비교 하였다. 또한 도라지의 중금속 흡수 특성을 알아보기 위해 서 토양 중 중금속 함량 (총함량, 유효태 함량)과 도라지 중 금속 함량간의 선형회귀 분석을 실시하였으며, 이를 위해서 측정된 농도 수치를 로그 $(\mathrm{Log})$ 수치로 변환하여 측정값의 분포를 표준화한 후 회귀분석을 실시하였다.

\section{Results and Discussion}

도라지 재배토양 특성 도라지를 재배하고 있는 경남 과 강원도 조사대상 토양의 유기물, 유효인산, 치환성 양이 온의 평균 함량은 우리나라 밭토양 평균 수치보다 낮은 것 으로 나타났으며, 토양 $\mathrm{pH}$ 는 평균 6.0 으로 밭토양 평균 수 치와 같았다 (Table 1). 그 외 평균 $\mathrm{EC}$ 는 $0.08 \mathrm{dS} \mathrm{m}^{-1}$, 총질 소 농도는 $0.12 \%$ 였다. 도라지 재배지 토양의 점토함량은 7-32\% 정도의 분포를 보이며, 대부분의 토성은 양토 $(38 \%)$ 와 사양토 (43\%)로 나타났다.

Table 1. Physicochemical properties of the soils collected from balloon flower cultivated sites.

\begin{tabular}{|c|c|c|c|c|c|c|c|c|c|c|}
\hline & \multirow{2}{*}{$\begin{array}{c}\mathrm{pH} \\
(1: 5)\end{array}$} & \multirow{2}{*}{$\begin{array}{l}\mathrm{TN} \\
(\%)\end{array}$} & \multirow{2}{*}{$\begin{array}{l}\text { O.M. } \\
\left(\mathrm{g} \mathrm{kg}^{-1}\right)\end{array}$} & \multirow{2}{*}{$\begin{array}{l}\text { Avail.-P } \\
\left(\mathrm{mg} \mathrm{kg}^{-1}\right)\end{array}$} & \multicolumn{4}{|c|}{ EX. Cations } & \multirow{2}{*}{ 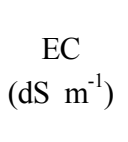 } & \multirow{2}{*}{$\begin{array}{l}\text { Clay } \\
(\%)\end{array}$} \\
\hline & & & & & $\mathrm{Ca}$ & $\begin{array}{l}\mathrm{Mg} \\
(\mathrm{cmol}\end{array}$ & $\begin{array}{c}\mathrm{K} \\
-1\end{array}$ & $\mathrm{Na}$ & & \\
\hline Min & 4.6 & 0.002 & 6.4 & 0.5 & 0.3 & 0.2 & 0.2 & 0.02 & 0.02 & 7 \\
\hline Median & 6.0 & 0.10 & 17.8 & 141 & 3.2 & 1.0 & 0.4 & 0.05 & 0.07 & 17 \\
\hline Max & 7.8 & 0.25 & 53.8 & 389 & 9.8 & 3.1 & 2.6 & 0.22 & 0.46 & 32 \\
\hline Ave & 6.0 & 0.12 & 21.6 & 118 & 3.5 & 1.0 & 0.6 & 0.06 & 0.08 & 18 \\
\hline$<$ OR $(\%)$ & 51 & - & 52 & 97 & 78 & 82 & 51 & - & - & - \\
\hline$>$ OR $(\%)$ & 32 & - & 21 & 0 & 8 & 5 & 23 & - & 0 & - \\
\hline a Optimal range (OR) & $6.0-6.5$ & - & $20-30$ & $300-500$ & $5.0-6.0$ & $1.5-2.0$ & $0.5-0.6$ & - & $0-2$ & - \\
\hline${ }^{\mathrm{b}}$ Average in upland soil & 6.0 & - & 22 & 587 & 5.8 & 1.7 & 0.81 & - & - & - \\
\hline
\end{tabular}

${ }^{a}$ Optimal range for balloon flower cultivation in Korea (provided by RDA)

${ }^{\mathrm{b}}$ Average values in cultivated upland soil in Korea (RDA, 2010) 
흙토람을 통해서 제공되고 있는 도라지에 대한 적정 범 위와 비교해 볼 때 조사를 진행했던 재배농가 토양의 화학 성분 대부분이 적정 범위를 벗어난 것으로 나타났다. 토양 $\mathrm{pH}$ 와 유기물에 대해서 조사시료의 $51,52 \%$ 가 각각 적정범 위 보다 낮은 수치를 보였고, $32,21 \%$ 가 적정범위 보다 높 은 수치를 보였다. 유효인산은 조사시료 $97 \%$ 가 최소 적정수 치로 제시되고 있는 $300 \mathrm{mg} \mathrm{kg}^{-1}$ 이하로 나타났으며, 과잉 으로 조사된 시료는 없었다. 치환성 양이온도 대부분 적정 수치보다 낮게 관리되고 있는 것으로 나타나, 조사시료의 $78,82,51 \%$ 가 각각 $\mathrm{Ca}, \mathrm{Mg}, \mathrm{K}$ 의 최소 적정수치보다 낮았 다. 토양의 화학적 특성은 재배 작물에 대한 양분관리를 위 해서 매우 중요한 정보를 제공한다. 본 조사결과를 종합해 볼 때, 경남과 강원지역 도라지 재배농가에서 지금까지 대 부분 시비기준에 못 미치는 수준으로 양분관리를 하고 있어 추후 적정 양분 관리를 위해서 영농지도가 필요할 것으로 판단된다.

도라지 재배토양 중금속 농도 경남과 강원도 내 도 라지 재배 토양의 중금속 농도는 우리나라 평균 배경 농도 와 비슷한 수준으로 토양환경보전법 상의 중금속 기준농도 를 초과하는 시료는 없었다 (Table 2). 현재까지 우리나라 토양 중 중금속 배경농도에 대한 조사보고가 다양하게 있었 으나, 조사범위 및 대상으로 하고 있는 토양이 서로 달라 각 중 금속에 대해서 제시하고 있는 배경농도가 서로 다르다 (Yoon et al., 2009; Kwon et al., 2013; RDA, 2012). 따라서 본 연 구에서는 도라지 재배토양 분석 결과값과 기존 배경농도와

Table 2. Total heavy metal concentration in the soils collected from balloon flower cultivated sites.

\begin{tabular}{|c|c|c|c|c|c|}
\hline \multirow{2}{*}{ Province } & & $\mathrm{Cd}$ & $\mathrm{Cu}$ & $\mathrm{Pb}$ & $\mathrm{Zn}$ \\
\hline & & \multicolumn{4}{|c|}{$\left(\mathrm{mg} \mathrm{kg}^{-1}\right)$} \\
\hline \multirow{4}{*}{$\begin{array}{c}\text { Kyoungnam } \\
(\mathrm{n}=47)\end{array}$} & Min & 0.01 & 6.6 & 0.0 & 20.6 \\
\hline & Median & 0.07 & 20.5 & 11.6 & 55.5 \\
\hline & Max & 0.36 & 177.7 & 45.6 & 93.3 \\
\hline & Ave & 0.16 & 24.3 & 12.5 & 53.2 \\
\hline \multirow{4}{*}{$\begin{array}{c}\text { Kangwon } \\
(\mathrm{n}=18)\end{array}$} & Min & 0.00 & 5.6 & 6.2 & 43.0 \\
\hline & Median & 0.03 & 11.0 & 9.2 & 50.9 \\
\hline & Max & 0.06 & 40.1 & 18.1 & 75.9 \\
\hline & Ave & 0.03 & 14.7 & 10.0 & 55.2 \\
\hline \multicolumn{2}{|c|}{${ }^{\mathrm{a}}$ Background value $\mathrm{A}$} & 0.19 & 13.0 & 16.0 & 51.0 \\
\hline \multicolumn{2}{|c|}{${ }^{\mathrm{b}}$ Background value $\mathrm{B}$} & 0.22 & 33.8 & 24.4 & 41.3 \\
\hline \multicolumn{2}{|c|}{${ }^{c}$ Average for paddy field } & 0.59 & 15.2 & 18.3 & 53.6 \\
\hline \multicolumn{2}{|c|}{${ }^{\mathrm{d}}$ Standard limit } & 4.00 & 150.0 & 200.0 & 300.0 \\
\hline
\end{tabular}

${ }^{a}$ Forest soil based natural background value reported by Yoon et al. (2009) ${ }^{b}$ Mother rook based natural background value reported by Kwon et al. (2013) 'Average values for paddy field in Korea provided by RDA (2011)

${ }^{\mathrm{d}}$ Standard limit registered in Soil Conservation Act 2009, Korea
의 비교 신뢰성을 확보하기 위해서 세 가지 대표적인 배경 준위 농도를 Table 2에 제시하였다.

Yoon et al. (2009)은 우리나라 산림토양 중 배경농도를 측정하여 발표하였는데, 제시하고 있는 세 가지 배경농도 중에서 카드뮴, 구리, 납이 각각 $0.19,13.0,16.0 \mathrm{mg} \mathrm{kg}^{-1}$ 로 가장 낮은 수준이었다. 이 수치와 비교해 볼 때, 경남지역 도라지 재배 토양의 카드뮴과 납의 평균 수치는 오히려 더 낮았다. 반면에 구리 농도는 $24.3 \mathrm{mg} \mathrm{kg}^{-1}$ 로 다소 높았으 나, Kwon et al. (2013)이 보고한 모암 종류에 따른 구리의 배경농도 보다는 낮은 수준으로 외부 영향은 없는 것으로 판단할 수 있었다. 아연에 대해서는 Kwon et al. (2013)이 보고한 배경농도가 $41.3 \mathrm{mg} \mathrm{kg}^{-1}$ 로 가장 낮았으며, 이 수치 와 비교해서 본 연구에서 측정된 아연은 $53.2 \mathrm{mg} \mathrm{kg}^{-1}$ 로 다 소 높았다. 그러나 역시 RDA (2011)와 Yoon et al. (2009)이 제시하고 있는 배경농도와는 비슷한 수준으로 외부 영향에 의한 오염도 증가는 없는 것으로 판단할 수 있었다. 경남지 역과 강원도 지역의 도라지 재배토양 내 중금속 농도를 비 교했을 때 경남지역 토양에서 카드뮴과 납이 강원도 토양보 다 다소 높았으나, 이 역시 배경농도 수준으로 두 지역 토양 모두 외부로부터의 중금속 유입 가능성이 없었다고 할 수 있었다.

도라지 중금속 농도 및 흡수 특성 본 연구에서 측 정된 도라지 뿌리의 중금속 농도 (건물중 기준)와 비교를 위 해서 '식품위생법'과 '약사법'에 고시되어 있는 카드뮴과 납 의 중금속 기준농도 및 구리와 아연에 대한 식물독성 (두류) 발현 농도를 Table 3 에 나타내었다.

경남과 강원지역에서 재배되고 있는 도라지의 구리 및 아연 축적 농도는 각각 평균 약 $5.8 \mathrm{mg} \mathrm{kg}^{-1}$, 약 $30 \mathrm{mg} \mathrm{kg}^{-1}$ 수준으로 Miyazawa et al. (2002)가 제시한 두류에 대한 식 물 독성 농도인 구리 $64 \mathrm{mg} \mathrm{kg}^{-1}$ 와 아연 $130 \mathrm{mg} \mathrm{kg}^{-1}$ 보다 횔씬 낮았다. 구리와 아연의 경우 농작물에 대한 식물 독성 발현이 문제가 되지만 (Channey, 2012), 인체 위해성에 대 한 우려가 적기 때문에 현재까지 식품위생법에 구리와 아연 에 대한 기준이 설정되어 있지 않다.

식품위생법 및 약사법에 고시되어 있는 농산물 및 생약 (약용작물)에 대한 납의 기준과 비교해서 본 연구에서 분석 한 도라지의 납 축적 농도는 매우 낮은 수준으로 안전성이 인정되었다. Table 3 에 나타낸 도라지의 중금속 축적 농도 는 건물중 기준 농도로써 약사법에 고시되어 있는 기준(건 물중 기준)과는 직접 비교가 가능하다. 그러나 식품위생법 에 고시되어 있는 기준은 생체중 기준이기 때문에 본 연구 에서 측정한 도라지 뿌리의 평균 수분함량 $75.3 \%$ 를 감안하 여 고시된 기준을 건물중 기준으로 환산하면 식품위생법 상 납에 대한 기준을 $8.1 \mathrm{mg} \mathrm{kg}^{-1}$ 로 볼 수 있다. 같은 방법으로 카드뮴에 대한 식품위생법 상 기준을 환산하면 $0.81 \mathrm{mg}$ 
Table 3. Total heavy metal concentration in the root of balloon flower collected.

\begin{tabular}{|c|c|c|c|c|c|}
\hline \multirow{2}{*}{ Province } & & $\mathrm{Cd}$ & $\mathrm{Cu}$ & $\mathrm{Pb}$ & $\mathrm{Zn}$ \\
\hline & & \multicolumn{4}{|c|}{ (mg kg $\left.{ }^{-1} \mathrm{DW}\right)$} \\
\hline Kyoungnam & Min & 0.21 & 3.7 & 0.3 & 18.0 \\
\hline \multirow[t]{3}{*}{$(\mathrm{n}=47)$} & Median & 0.35 & 5.5 & 0.5 & 27.7 \\
\hline & Max & 0.88 & 9.9 & 2.7 & 66.2 \\
\hline & Ave & 0.39 & 5.8 & 0.7 & 29.9 \\
\hline \multirow{4}{*}{$\begin{array}{c}\text { Kangwon } \\
(\mathrm{n}=18)\end{array}$} & Min & 0.20 & 3.3 & 0.3 & 19.8 \\
\hline & Median & 0.26 & 5.9 & 0.6 & 27.3 \\
\hline & Max & 0.42 & 8.3 & 1.1 & 48.9 \\
\hline & Ave & 0.27 & 5.8 & 0.6 & 30.6 \\
\hline \multicolumn{2}{|c|}{$>$ SLRV (\%) } & $1.5(1)$ & & 0 & \\
\hline \multicolumn{2}{|c|}{ >SLMP (\%) } & $54(35)$ & & 0 & \\
\hline \multicolumn{2}{|c|}{$\begin{array}{l}\text { Standard limits for root } \\
\text { vegetable (SLRV) }\end{array}$} & $\begin{array}{c}0.20 \\
(0.81)\end{array}$ & - & $\begin{array}{c}2.0 \\
(8.1)\end{array}$ & - \\
\hline \multicolumn{2}{|c|}{$\begin{array}{c}\text { Standard limits for } \\
\text { medicinal plant (SLMP) }\end{array}$} & 0.30 & - & 5.00 & - \\
\hline \multicolumn{2}{|c|}{$\begin{array}{c}\text { Tolerable level for bean } \\
\text { plant }\end{array}$} & - & 64 & - & 130 \\
\hline
\end{tabular}

$\mathrm{kg}^{-1}$ 이 된다.

본 조사에서 눈에 띄는 점은 앞서 살펴본 바와 같이 도라 지 재배 토양 중 중금속의 총농도는 우리나라 토양의 배경 농도 수준으로 나타났음에도 불구하고, 도라지 뿌리에 축적 된 카드뮴은 식품위생법 기준을 적용했을 때 $1.5 \%$ 에 해당하 는 1 개 시료가, 약사법 기준 $(0.3 \mathrm{mg} \mathrm{kg}-1$, 건물중 기준)을 적용했을 경우 $54 \%$ 에 해당하는 35 개 시료가 기준을 초과하 는 것으로 나타난 것이다. 이와 같이 기준을 초과하는 결과 가 나타난 것은 두 가지 측면에서 검토해야 할 필요가 있다. 먼저, 우리나라의 식품위생법과 약사법에서 고시하고 있는 카드뮴에 대한 기준이 필요이상으로 엄격하다는 것이다. 국 제사회에서 농산물을 통한 카드뮴의 인체 위해성 발현 사례 는 카드뮴에 오염된 $\left.>1.0 \mathrm{mg} \mathrm{kg}^{-1}\right)$ 쌀을 장기간 섭취한 경우 에 국한되어서 보고되고 있으며, 그 외 농산물 섭취로 인한 인체 위해성 발현 보고는 매우 제한적이라고 하였다 (Chaney, 2012). 또한, 식품 종류별로 축적된 카드뮴의 인체흡수도가 다르기 때문에 정확한 생체유효도 (bioavailability) 시험을 거쳐 식품별 카드뮴 기준이 정해질 필요가 있다고 하였다. 우리나라에서 적용하고 있는 두 법령간에도 카드뮴에 대한 적용 기준이 서로 상이하여, 약사법에 고시된 기준 $(0.3 \mathrm{mg}$ $\left.\mathrm{kg}^{-1}\right)$ 이 식품위생법 상의 기준 $(0.81 \mathrm{mg} \mathrm{kg}$, 건물중 기준 으로 환산한 경우)보다 약 2.5 배 낮은 수치이다. 납의 기준 도 식품위생법은 $8.1 \mathrm{mg} \mathrm{kg}^{-1}$, 약사법은 $5.0 \mathrm{mg} \mathrm{kg}^{-1}$ 으로 차이가 있다.

두 번째로 검토해야 할 사항은 우리나라 토양환경보전법 에 고시된 중금속 기준이 총함량 기준이기 때문에 농경지에
서 농작물의 중금속 흡수 특성을 반영하고 있지 못하는 점 이다. 식물의 중금속 흡수는 토양 중 중금속의 총농도에 의해 결정되기 보다는 식물유효태 농도에 의해서 결정된다 (Kim et al., 2012). 본 연구에서도 식품위생법 상의 기준을 초과한 도라지 시료 채취 지점의 토양 중 카드뮴 총농도는 약 0.1 $\mathrm{mg} \mathrm{kg}^{-1}$ 로 배경농도 보다도 낮은 수준이었으나 식물유효태 농도 $\left(1 \mathrm{M} \mathrm{NH}_{4} \mathrm{NO}_{3}\right.$ 추출법에 의한 농도)는 $40 \mathrm{ug} \mathrm{kg}^{-1}$ 로 조 사한 65 개 시료 중 가장 높았다. 또한 약사법 기준을 초과한 도라지 시료를 채취한 지점의 토양 중 식물유효태 평균 농 도는 $9.3 \mathrm{ug} \mathrm{kg}^{-1}$ 로 기준 이하 시료에 해당한 토양 시료의 식물유효태 농도 $3.3 \mathrm{ug} \mathrm{kg}^{-1}$ 보다 약 3 배 높았다. 이와 같 은 결과는 안전한 농산물 생산과 관련한 농경지 토양의 중 금속 관리를 위해서 총농도 기준과 더불어 유효태 농도에 기초한 기준 설정 및 관리가 필요하다는 것을 시사한다.

경남과 강원지역간 도라지 뿌리 내 중금속 농도 비교에 서는 카드뮴을 제외한 다른 중금속에서는 차이가 나타나지 않았다. 카드뮴의 경우 경남지역은 평균 $0.39 \mathrm{mg} \mathrm{kg}^{-1}$ 로 $0.27 \mathrm{mg} \mathrm{kg}^{-1}$ 을 나타낸 강원도 보다 다소 높았으며, 이 결 과는 앞서 살펴본 두 지역간 토양 중 카드뮴 농도 차이를 반 영하고 있는 것으로 판단되었다.

도라지 뿌리의 중금속 흡수 특성을 알아보고자, 도라지 뿌리의 연수 증가에 따른 중금속 축적 농도 차이를 비교하 였으며, 토양 중 중금속의 유효태 함량 및 유효태 영향인자 와 뿌리 내 축적 농도와의 상관분석을 실시하였다. 도라지 는 짧게는 1 년근 길게는 10 년근까지 재배가 이루어지고 있 다. 연수 증가에 따른 중금속 축적 농도 차이에 대한 고찰은 뿌리가 토양 중 중금속에 노출된 시간의 증가 및 도라지 뿌 리의 체적 증가가 중금속 축적 농도와 관계가 있는지를 알 아보기 위함이었다. 조사대상이었던 4종류의 중금속 중에 서 아연에서만 1-2년근에 축적되는 농도가 3년근 이상에서 축적되는 농도보다 유의 ( $\mathrm{p}\langle 0.05)$ 하게 높았고, 그 외 중금속 에서는 연수 증가에 따른 유의차가 인정되지 않았다. 다만 Fig. 1에서 보는 바와 같이, 카드뮴과 아연은 연수 증가에 따라 축적 농도가 감소하는 경향이 나타났는데, 이는 뿌리 체적 증가에 따른 희석효과가 반영된 것으로 볼 수 있었다. 반대로 납은 연수가 증가할수록 축적 농도가 증가하는 경향 을 나타냈다. 본 연구는 기본 조건 (도라지 재배 토양의 중 금속 농도가 동일해야 하는 점)이 제어되지 않은 상태에서 이와 같은 비교를 실시했다는 단점을 가지고 있으나, 그럼 에도 불구하고 그 경향성은 추후 연수에 따른 중금속 축적 농도 차이에 대한 확대 연구가 필요함을 시사한다.

상관분석에서 토양 중 중금속 총함량과 도라지 뿌리의 함량간에는 4 종류 중금속 모두에서 유의한 상관관계가 없 는 것으로 나타난 반면, $1 \mathrm{M} \mathrm{NH}_{4} \mathrm{NO}_{3}$ 로 추출하여 분석한 식 물유효태 함량 중 카드뮴과 아연이 뿌리 내 카드뮴 $(\mathrm{r}=0.34$, $\mathrm{p}<0.05)$ 과 아연 $(\mathrm{r}=0.33, \mathrm{p}<0.05)$ 의 축적 농도와 정의 상관 

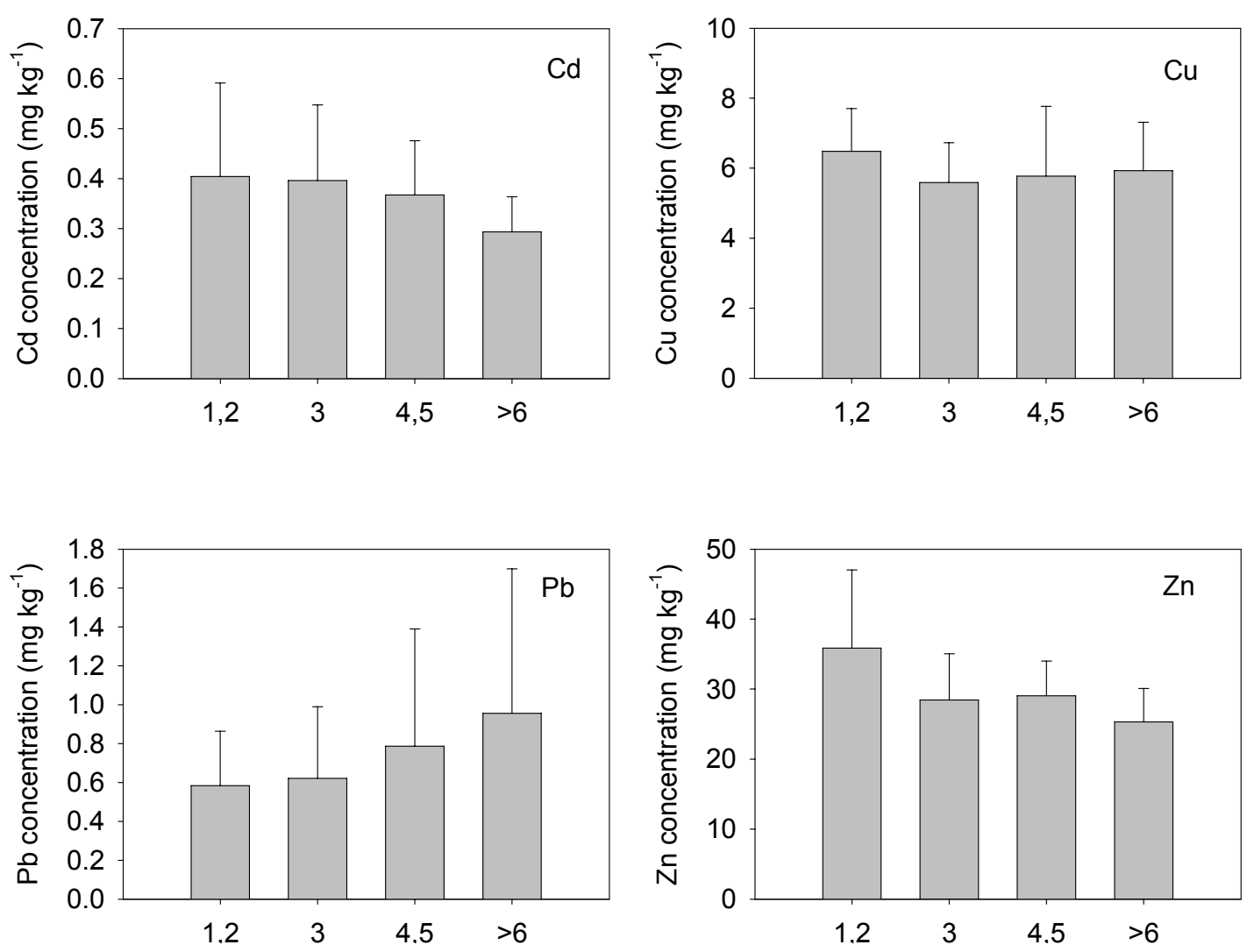

Fig. 1. Heavy metal concentrations in balloon flower roots cultivated for different durations ( $x$ axis is the cultivated years and the different letter implies significant difference at $\mathbf{p}<0.05)$.

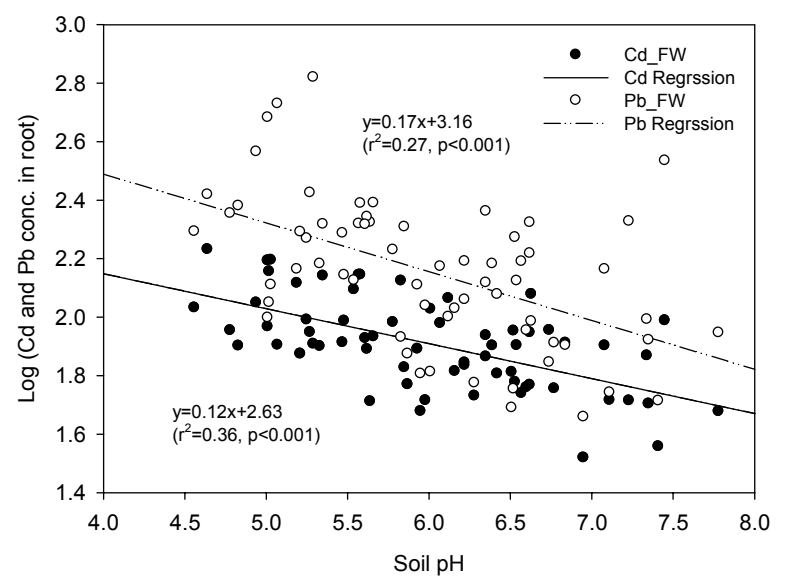

Fig. 2. Comelations between soil $\mathrm{pH}$ and $\log$ transformed $\mathrm{Cd}$ or $\mathrm{Pb}$ concentrations in balloon flower roots.

관계를 나타내었다. 이와 같은 결과는 식물에 의한 중금속 흡수가 토양 중 중금속의 유효태 함량에 의해 결정된다는 기존 연구 보고와 일치하였다 (Kim et al., 2013). 본 연구 에서는 다른 기존 연구에서보다 상관계수가 다소 낮게 나타 났는데, 이는 조사 대상 토양 시료의 중금속 농도가 대부분 배경농도 수준으로 낮았고 농도 분포 범위도 넓지 않았기 때문인 것으로 판단할 수 있었다. 특이적으로 본 연구에서 는 토양 $\mathrm{pH}$ 와 도라지 뿌리 내 카드뮴 및 납과 직접적인 부
의 유의한 ( $\mathrm{p}<0.001)$ 상관관계를 나타내었다 (Fig. 2).

이는 $\mathrm{pH}$ 가 높은 토양에서는 카드뮴과 납의 유효태 농도 가 상대적으로 낮고 $\mathrm{pH}$ 가 낮은 토양에서는 카드뮴과 납의 유효태 농도가 상대적으로 높기 때문인 것으로 해석 할 수 있다. 토양 $\mathrm{pH}$ 는 여러 가지 토양의 특성 중 단일인자로써는 중금속의 유효도에 가장 크게 영향을 미치는 인자로써 (Kim et al., 2010; Kumpiene et al., 2008), 토양 pH 증가는 토 양입자 표면으로부터 탈수소 작용 (deprotonation)을 야기 하고 이로 인해서 토양입자의 음전하량을 증가시켜 양이온 중금속에 대한 흡착력을 높게 한다. 또한 토양 $\mathrm{pH}$ 증가를 유발시키는 수산화이온 $\left(\mathrm{OH}^{-}\right)$은 중금속과 결합하여 수산화 -중금속 화학종을 형성하는데, 수산화-중금속 화학종은 중 금속 자유이온 화학종보다 토양에 대한 흡착능력이 크기 때문 에 중금속의 유효도가 감소한다 (Naidu et al., 1994; Bolan et al., 2003). 이와 같은 결과를 토대로 인체 위해성이 높은 카드뮴과 납에 대한 도라지 흡수를 저감시키기 위해서는 현 재 도라지 재배토양의 평균 $\mathrm{pH}$ (6.0)를 높이는 방향으로 관 리가 이루어져야 할 것으로 판단된다. 앞서 기술한 바와 같 이 오염이 되지 않은 토양에서 카드뮴이 약사법 상의 기준 치 이상으로 검출되는 도라지가 생산되고 있는 점을 감안할 때, 재배토양의 $\mathrm{pH}$ 관리를 통해서 기준치를 초과하는 도라 지 생산 문제를 다소 해결할 수 있을 것으로 보인다. 


\section{Conclusions}

경남과 강원도 지역 도라지 재배 토양의 화학적 특성 (토 양 $\mathrm{pH}$, 유기물, 유효인산, 치환성 양이온 함량)은 대부분 도 라지 재배를 위한 적정 수준보다 낮은 것으로 나타나 도라 지에 대한 시비처방 기준에 부합하는 양분관리가 필요할 것 으로 판단된다. 도라지 재배토양의 중금속 (카드뮴, 구리, 납, 아연) 농도는 우리나라 배경농도 수준으로 외부적인 요 인에 의한 농도 변화는 없는 것으로 판단되었으나, 재배되 고 있는 도라지 일부에서 뿌리의 카드뮴 농도가 식품위생법 상의 농산물 (근채류) 기준 및 약사법 상의 생약 (약용작물) 기준을 초과하였다. 따라서 관련 기준의 검토 및 도라지 뿌 리의 카드뮴 흡수를 저감할 수 있는 방안이 모색되어야 할 것이다. 도라지에 의한 카드뮴 흡수 저감은 본 연구결과에 서 보여준 바와 같이 토양 $\mathrm{pH}$ 를 다소 높은 수준으로 관리하 여 토양 중 카드뮴의 유효태 농도를 낮게 유지하는 방법을 활용할 수 있을 것으로 보인다.

\section{References}

Bolan, N.S., D.C. Adriano, P.A. Mani. and A. Duraisamy. 2003. Immobilization and phytoavailability of cadmium in variable charge soils. II. Effect of lime addition. Plant Soil 251: 187-198.

Bray, R.H. and L.T. Kurtz. 1945. Determination of total, organic, and available forms of phosphorus in soils. Soil Sci. 59:39-45.

Chaney, R.F. 2012. Food safety issues for mineral and organic fertilizers. Advances in Agronomy 117: 51-115

DIN (Deutsches Institut für Normung). 1995. Soil quality extraction of trace elements with ammonium nitrate solution. DIN 19730, Beuth Verlag, Berlin.

Franco, A., M. Schuhmacher, E. Rosa, J.L. Domingo. 2006. Application of cattle manure as fertilizer in pastureland: Estimating the incremental risk due to metal accumulation employing a multicompartment model. Environ. Int. 32: 724-732.

Hwang, E.H., S.M. Wee, P.K. Lee, S.H. Choi. 2000. A study on the heavy metal contamination of paddy soil in the vicinity of the Seosung Pb-Zn mine. J. KoSES 5(2): 67-85.

Kim, K.R., G. Owens, and S.I. Kwon. 2010. Influence of Indian mustard (Brassica juncea) on rhizosphere soil solution chemistry in long-term contaminated soils: A rhizobox study. J. Environ. Sci. 22:98-105.

Kim, K.R., J.G. Kim, J.S. Park, M.S. Kim, G. Owens, G.H. Youn, and J.S. Lee. 2012. Immobilizer-assisted management of metal-contaminated agricultural soils for safer food production.
J. Environ. Manage. 102: 88-95.

Kumpiene, J., A. Lagerkvist, and C. Maurice. 2008. Stabilization of $\mathrm{As}, \mathrm{Cr}, \mathrm{Cu}, \mathrm{Pb}$ and $\mathrm{Zn}$ in soil using amendments - A review. Waste Manage. 28:215-225.

Kwon, S.I., G.B. Jung, W.I. Kim, S.C. Hong, M.K. Kim, M.J. Chae, and K.H. So. 2013. Background metal concentrations of the soil by parent rocks in Korea. Korean Soc. Environ. Agri. 2013 conference proceeding $\mathrm{p} 309$.

Lee, S.H., H. Choi, and C-H Park. 2003. Determination of heavy metal contents in oriental medical materials and the effect of washing. Korean J. Biotechnol. Bioeng. 18(2): 90-93.

Lee, H., J. Seo, M. Oh, I. Gang, J. Park, K. Seo, D. Ha, E. Kim. 2010. A survey on harmful materials of commercial medical herb in Gwangju Area. J. Fd Hyg. Safety 25(2): 83-90.

MAFRA (Ministry of Agriculture, Food and Rural Affairs). 2011 Food Sanitation Act 2011. Seoul, Korea.

MFDS (Ministry of Food and Drug Safety). 2010. Pharmaceutical Affairs Act 2010. Seoul, Korea.

Miller, W.P. and M. Miller. 1987. A micro pipette method for soil mechanical analysis, Commun. Soil Sci. Plant Anal. 18: 1-15.

MIRECO (Korea Mine Reclamation Corporation). 2012. Mine Reclamation Statistical Yearbook. Korea Mine Reclamation Corporation, Seoul, Korea.

Miyazawa, M., S.M.N. Giminez, M.J.S. Yabe, E.L. Oliveira, and M.Y. Kamogawa. 2002. Absorption and toxicity of copper and zinc in bean plants cultivated in soil treated with chicken manure. Water Air Soil Pollut. 138: 211-222.

MoE (Ministry of Environment). 2012. National soil survey and investigation of soil contamination. Seoul, Korea.

NAAS, 2010. Analysis methods for soil chemical properties. Publication No. 11-1390802-000282-01. NAAS, Suwon, Korea. Naidu R., N.S. Bolan, R.S. Kookana, and K.G. Tiller. 1994. Ionic-strength and $\mathrm{pH}$ effects on the adsorption of cadmium and the surface charge of soils. Eur. J. Soil Sci. 45: 419-429.

RDA, 2012. Annual report 2012: monitoring project on agroenvironmental quality. RDA. Suwon, 2012.

Rio, M., A. franco-Uria, E. Abad, and E. Roca. 2011. A risk-based decision tool for the management of organic waste in agriculture and farming activities. J hazard. Mater. 185: 792-800.

Sumner, M.E. and W.P. Miller. 1996. Cation exchange capacity and exchange coefficients. p. 1201-1230. In: D.L. Sparks et al. (eds). Methods of soil analysis. part 3. Chemical method. SSSA and ASA, Madison, WI, USA.

Yoon, J.K., D.H. Kim, T.S. Kim, J.G. Park, I.R. Chung, J.H. Kim. and H. Kim. 2009. Evaluation on natural background of the soil heavy metals in Korea, J. Soil Groundwater Env. 14(3): 32-39. 